\title{
BIOSYNTHESIS OF PROGESTERONE FROM ENDOGENOUS STEROID PRECURSOR BY THE GUINEA-PIG PLACENTA
}

\author{
VERONICA K. PIZIAK* AND A. M. GAWIENOWSKI \\ Department of Biochemistry, University of Massachusetts, \\ Amherst, Massachusetts 01003, U.S.A.
}

(Received 16th Fune 1972)

\begin{abstract}
Summary. The supernatant resulting from centrifugation of a homogenate of the central portion of the guinea-pig placenta at $1000 \mathrm{~g}$ was found to synthesize progesterone from endogenous precursor. Addition of an NAD- or NADPH-generating system stimulated progesterone production.
\end{abstract}

Placental steroidogenesis in the guinea-pig is of special interest because this animal shares with the human the ability to maintain pregnancy if ovariectomized during the latter half of gestation. This observation indicates that the guinea-pig placenta synthesizes progesterone. Heap \& Deanesly (1966) found that the plasma progesterone concentration was correlated with placental weight in the ovariectomized guinea-pig. They also reported a fivefold higher progesterone level in the plasma after passage through the uterus. However, Ferguson \& Christie (1967), using histochemical methods, were unable to detect $\Delta-3 \beta$-hydroxysteroid dehydrogenase in the guinea-pig placenta during the latter portion of gestation. Recently, Bedwani \& Marley (1971) were able to show conversion of exogenous pregnenolone to progesterone by guinea-pig placental slices.

This report describes the biosynthesis of progesterone in the guinea-pig placenta from endogenous steroid precursor.

Placentae were obtained by Caesarean section from randomly bred guineapigs during the last 5 days of pregnancy as determined by the width of the pubic opening (Phillips, Wolfe \& Gordon, 1959). The cord and the decidua basalis were discarded. The central placental tissue located between the cord and the mesometrial pole of the uterus were dissected free and homogenized in a hand homogenizer with a solution containing 0.25 M-sucrose: Krebs' Ringer phosphate buffer, $\mathrm{pH} 7 \cdot 4: 0.04 \mathrm{M}$-nicotinamide $(11: 5: 1)$, using $1 \mathrm{ml}$ of solution for each gram of tissue. The homogenate was centrifuged at $1000 \mathrm{~g}$ for $10 \mathrm{~min}$, and the supernatant used for incubation.

The supernatant was incubated for $4 \mathrm{hr}$ at a temperature of $35^{\circ} \mathrm{C}$ in a medium containing varying amounts of a nicotinamide-adenine dinucleotide

\footnotetext{
* Present address: Department of Medicine, Division of Endocrinology, College of Medicine, University of Florida, Gainesville, Florida 32601, U.S.A.
} 
phosphate, reduced, generating system (NADPH and glucose-6-phosphate), NAD, and Krebs' Ringer buffer at $\mathrm{pH} 7 \cdot 4$. Supernatant equivalent to at least $1 \mathrm{~g}$ wet weight of tissue was added to each flask and incubated under a $95 \%$ $\mathrm{O}_{2}: 5 \% \mathrm{CO}_{2}$ atmosphere. A portion of the supernatant frozen at zero time gave the initial level of progesterone. Incubations were stopped by the addition of dry ice.

Known amounts of $\left[4-{ }^{14} \mathrm{C}\right]$ progesterone (specific activity $65 \mu \mathrm{Ci} / \mathrm{mg}$ ) were added to each flask before extraction to check efficiency of recovery. The average recovery was $49 \%$. Samples were extracted with diethyl ether and separated by two-dimensional thin-layer chromatography in hexane: ethyl acetate (5:2) (Armstrong, O'Brien \& Greep, 1964) and chloroform: methanol $(12: 1)$. Isolated pregnenolone and progesterone and the dinitrophenylhydrazone derivative of isolated progesterone (Shriner, Fuson \& Curtin, 1956) had the same mobilities as standards in these systems.

Table 1. Yields of progesterone and pregnenolone from guinea-pig placental homogenate

\begin{tabular}{l|c|c|c}
\hline \multicolumn{1}{c|}{$\begin{array}{c}\text { Cofactors } \\
\text { added }\end{array}$} & Progesterone & Pregnenolone & No. of experiments \\
\hline $\begin{array}{c}- \\
2 \mathrm{mg} \mathrm{NADP}\end{array}$ & $0 \cdot 6 \pm 0 \cdot 4$ & - & 8 \\
$\begin{array}{l}3.2 \mathrm{mg} \mathrm{G}-6-\mathrm{P} \\
2 \mathrm{mg} \mathrm{NADP}\end{array}$ & $2 \cdot 7 \pm 1 \cdot 2$ & - & 6 \\
$3.2 \mathrm{mg} \mathrm{G}-6-\mathrm{P}$ & $6 \cdot 6 \pm 1 \cdot 6$ & - & 6 \\
$\begin{array}{l}3 \mathrm{mg} \mathrm{NAD} \\
2 \mathrm{mg} \mathrm{NADP}\end{array}$ & - & $180 \pm 60$ & 5 \\
\hline $3.2 \mathrm{mg} \mathrm{G}-6-\mathrm{P}$ & - & & \\
\hline
\end{tabular}

Progesterone and pregnenolone data expressed as mean concentrations in $\mu \mathrm{g} / \mathrm{g}$ wet $\mathrm{wt}$ of tissue \pm S.E. For abbreviations, see text. G-6-P = glucose-6-phosphate.

Isolated pregnenolone, the pregnenolone acetate derivative and progesterone had retention times which were identical to both external and internal standards on $3 \% \mathrm{OF}-1$ and $3 \%$ SE-30 gas chromatography columns (Anachrom ABS support 100/110 mesh) at several temperatures. A retention time for pregnenolone of 0.32 relative to progesterone was the same as that reported by Chamberlain, Morris \& Smith (1968).

The compounds were analysed with a Varian series 1200 gas chromatograph equipped with a flame ionization detector (temperature, 210 to $225^{\circ} \mathrm{C}$; flow rate, $25 \mathrm{ml}$ nitrogen $/ \mathrm{min}$ ). The limit of detection was $0.2 \mu \mathrm{g}$.

Incubations carried out with different longitudinal sections of the placenta revealed that progesterone was synthesized only in the central tissue. This portion was consistently equal to $50 \%$ of the placental tissue. Pregnenolone, the immediate precursor of progesterone, was isolated from placental tissue at levels of 700 to $800 \mu \mathrm{g}$. Pregnenolone was also synthesized readily by placental preparations.

The results shown in Table 1 demonstrate pregnenolone and progesterone biosynthesis in the guinea-pig placenta from endogenous precursors and docu- 
ment the presence of ample amounts of pregnenolone to serve as a progesterone precursor. The amount of progesterone synthesized per gram of whole placental tissue $(0.3 \mu \mathrm{g} / \mathrm{g})$ is below the level of detection of Bedwani \& Marley (1971). Using only the central tissue of the placenta increases relative progesterone production by $50 \%$ and thus allows detection by our methods.

\section{REFERENCES}

Armstrong, D. T., O'Brien, J. \& Greep, O. (1964) Effects of luteinizing hormone on progestin biosynthesis in the luteinized rat ovary. Endocrinology, 75, 488.

Bedwani, J. R. \& Marley, P. B. (1971) Effect of ovariectomy and of various hormones on the synthesis of progesterone by the guinea-pig placenta in vitro. 7. Reprod. Fert. 26, 343.

Chamberlain, J., Morris, N. F. \& SMith, N. D. (1968) Gas chromatographic analysis of the unconjugated neutral non-polar steroids of human placenta. F. Endocr. 40,91.

Ferguson, M. M. \& Christie, G. A. (1967) Distribution of hydroxysteroid dehydrogenases in the placentae and foetal membranes of various mammals. F. Endocr. 38, 291.

Heap, R. B. \& Deanesly, R. (1966) Progesterone in systemic blood and placentae of intact and ovariectomized pregnant guinea-pigs. F. Endocr. 34, 417.

Phillirs, B. P., Wolfe, P. A. \& Gordon, H. D. (1959) Studies on rearing the guinea-pig germfree. Ann. N.Y. Acad. Sci. 78, 116.

Shriner, R. L., Fuson, R. C. \& GURTIN, D. Y. (1956) The systemic identification of organic compounds, 4th edn, p. 213. Wiley, New York. 